\title{
Management of Surgical Affections in Breeding Bulls
}

\author{
S.H. Sontakke*, Vinod H. Shende, V.V. Potdar, H.D. Kadam, \\ J.R. Khadse and A.B. Pande
}

BAIF Development Research Foundation, Central Research Station, Urulikanchan, Pune - 412 202, Maharashtra, India

*Corresponding author

\begin{tabular}{l} 
K e y w o r d s \\
$\begin{array}{l}\text { Breeding bulls, } \\
\text { Surgical affections, } \\
\text { Management }\end{array}$ \\
Article Info \\
$\begin{array}{l}\text { Accepted: } \\
\text { 07 July } 2019 \\
\text { Available Online: } \\
\text { 10 August } 2019\end{array}$ \\
\hline
\end{tabular}

A B S T R A C T

Data maintained on 742 breeding bulls of different breeds indicated that 213 cases were affected during 3 year period and 78 cases were treated by surgical interventions. Surgical cases recorded were as lameness 51 (23.94\%), major affections $09(4.23 \%)$ and minor affections $18(8.45 \%)$. Lameness was highest in purebred Holstein Friesian $(7.04 \%)$ compared to purebred Jersey bulls $(0.94 \%)$, while it was highest in crossbred Holstein Friesian (8.92\%) compared to crossbred Jersey bulls (1.41\%). Proper hoof trimming was mainly essential tool in early recovery of hoof lameness. The broad spectrum antibiotic (Amoxicillin-Cloxacillin) was parentally administered in ulceration cases. The major surgical affections recorded $(2.35 \%)$ were preputial prolapse, urolithasis, diaphragmatic hernia and horn avulsion. Minor surgical cases were highest in crossbred Jersey bulls $(2.35 \%)$ due to abscessation. The overall recovery rate in breeding bulls for lameness, major and minor surgical affections was 68.63, 66.67 and 66.67 per cent respectively.

\section{Implications}

The breeding bulls are special males among the herd male calves of high genetic value, Which may farm born or procured from the field level. The production or procurement of such bull is very lengthy, time consuming and expensive procedure. So the keen attention is to be given for the health by managing the surgical affections of breeding bull.

\section{Introduction}

Paucity of required number of breeding bulls for catering need of Artificial Insemination program in the country necessitate ensuring optimum utilization of the existing breeding bulls and building knowledge on culling rate due to health disabilities in general and surgical conditions in particular amongst breeding bulls at semen station. The experience so gathered is important for 
planning bull replacement strategy besides getting prepared for salvaging those for active service. Non availability or Very little information is available on indigenous cattle (Singh et al., 2005) on different surgical problems of breeding bulls under Indian conditions. In present paper, an attempt is made to deal with different surgical affections in breeding bulls, their therapeutic management and recovery rate.

\section{Materials and Methods}

Data on 742 breeding bulls belonging to breeds like Holstein Friesian (HF), Jersey (JY), crossbred Holstein Friesian (XHF), crossbred (XJY), Indigenous breed and buffalo bulls during 3 years (2008-2010) were compiled and analyzed. Out of 213 cases of different affections during the period under study, seventy eight (78) cases corrected by surgical interventions were recorded. These cases were further divided as lameness, major $\&$ minor surgical affections. Incidence of affection, therapeutic management and recovery rate of these cases were studied. Broad spectrum antibiotic (AmoxicillinCloxacillin) was parentally administered in ulceration cases and also in abscess of sole conditions after proper cleaning, trimming and bandaging of affected hooves. The non-foot origin lameness cases were treated with nervine tonic, analgesic and anti-inflammatory drugs. Major surgical affections were preputial prolapse, urolithasis, diaphragmatic hernia and horn avulsions, while minor surgical affection were wound, abscess and eye affections.

\section{Results and Discussion}

Breed wise surgical cases recorded, type of affection and recovery rate is presented in Table 1. Lameness was observed in 51 $(23.94 \%)$ cases. Major affections were in 09 $(4.23 \%)$ bulls, while minor surgical cases were $18(8.45 \%)$. Antihistaminic, anti-inflammatory
\& analgesic drugs were parentally administered in foot lameness cases. The broad spectrum antibiotic (AmoxicillinCloxacillin) was parentally administered in ulceration. Proper hoof trimming was found to be mainly effective for recovery of hoof lameness.

Average incidence of lameness problem encountered in bulls was 23.94 per cent, which closely resembles to the findings of Chenoweth et al., (2003). Incidence reported in dairy herds of different countries vary from 2.5 to 69 per cent in UK (Hedges et al., 2001), 46 per cent in USA (Warnick et al., 2001), 25 per cent in Scotland (Whitaker et al., 1983), 20.7 per cent in New Zealand (Tranter and Morris, 1991), 14.2 per cent in Ireland (Arkins, 1981) and 2.5 per cent in Australia (Jubb and Malmo, 1991). No published report regarding incidence of lameness in breeding bulls under Indian conditions was available in literate scanned by the authors.

Lameness was highest in purebred HF (7.04\%) compared to JY purebred bulls $(0.94 \%)$, while in crossbreds highest lamness was noticed in XHF (8.92\%) compared to XJY bulls $(1.41 \%)$. It was observed that HF and their crosses are more prone to lameness as compared to JY and XJY. The buffalo and JY had cent per cent recovery rate from the lameness. There are indications that certain breeds have predisposition for lameness. For example, sole ulcers occur predominantly in very large framed, purebred, Holstein-Friesian cows (Jubb and Malmo, loc. cit). HF bulls are more prone might be due to breed susceptibility, heavy body weight and hard bedding under Indian conditions.

The major surgical affections recorded were preputial prolapse, urolithasis, diaphragmatic hernia and horn avulsion. The major surgical problem was highest $(2.35 \%)$ and total recovery in buffaloes due to avulsion of horn. 


\begin{tabular}{|c|c|c|c|c|c|c|c|}
\hline \multicolumn{8}{|c|}{ Table.1 Breed wise surgical cases recorded, type of affections and recovery rate in breeding bulls (2008-10) } \\
\hline \multirow{2}{*}{ Breed } & \multirow{2}{*}{$\begin{array}{l}\text { No. of } \\
\text { bulls }\end{array}$} & \multicolumn{2}{|c|}{ Lameness cases } & \multicolumn{2}{|c|}{ Major surgical cases } & \multicolumn{2}{|c|}{ Minor surgical cases } \\
\hline & & \multirow{8}{*}{$\begin{array}{c}\text { No. of cases } \\
\text { (\% Affection) } \\
15(7.04) \\
02(0.94) \\
19(8.92) \\
03(1.41) \\
05(2.35) \\
07(3.29) \\
51(23.94)\end{array}$} & $\begin{array}{c}\text { Recovery } \\
\%\end{array}$ & $\begin{array}{l}\text { No. of cases } \\
\text { (\% Affection) }\end{array}$ & $\begin{array}{c}\text { Recovery } \\
\%\end{array}$ & \multirow{8}{*}{$\begin{array}{c}\text { No. of cases } \\
\text { (\% Affection) } \\
1(0.47) \\
0(0.0) \\
4(1.88) \\
5(2.35) \\
4(1.88) \\
4(1.88) \\
18(8.45)\end{array}$} & $\begin{array}{c}\text { Recovery } \\
\%\end{array}$ \\
\hline HF & 90 & & 46.67 & $0(0.00)$ & 0.00 & & 100 \\
\hline JY & 77 & & 100 & $0(0.00)$ & 0.00 & & 0.0 \\
\hline HFX & 135 & & 78.95 & $1(0.47)$ & 100.00 & & 75.0 \\
\hline JYX & 80 & & 66.67 & $1(0.47)$ & 0.00 & & 40.0 \\
\hline Indigenous & 145 & & 40.0 & $2(0.94)$ & 0.00 & & 75.0 \\
\hline Buffalo & 215 & & 100 & $5(2.35)$ & 100.00 & & 75.0 \\
\hline Overall & 742 & & 68.63 & $9(4.23)$ & 66.67 & & 66.67 \\
\hline
\end{tabular}

It might be due to infighting of bulls and major blow by head to steel frames of bull pens. The preputial prolapse case was corrected by prepuctomy and the affected bull after correction performed well for semen collection and there was no further prolapses or reduced quality, quantity of semen and libido. Such conditions are more frequently encountered in polled breeds of cattle because of absence of the retractor preputial muscles (Tyagi and Jitsingh, 2004). Preputial laceration usually leads to prolapse of the prepuce in bulls of Bos indicus breeds, as they are having pendulous preputial sheath and long prepuce (Wolfe, 2009).

Only one case of urolithiasis was recorded, which might be due to very hard drinking water $(>1200 \mathrm{ppm})$. It could be also due to high testosterone level in breeding bulls. The minor surgical cases included wound, abscess and eye affection. The minor surgical cases of abscess formation were highest in XJY bulls $(2.35 \%)$. The eye affections were corneal opacity, eye injury and few cases of keratoconjunctivitis. The Pendistrin-SH ointment having penicillin and steroid drugs were found effective in recovery of eye affections without any other therapy.

The overall incidence of lameness problem was 23.94 per cent in breeding bulls. Amongst exotic breeds, the lameness incidence was highest in HF bulls $(7.04 \%)$ and in crossbreds, it was highest in the same breed $(8.92 \%)$. The proper hoof trimming showed best recovery in hoof lesions leading to lameness. Buffalo bulls suffered highest cases of avulsion of horn $(2.35 \%)$ as a major surgical problems but the recovery was 100 per cent. The prepuctomy was final remedy to correct preputial prolapsed in breeding bulls. The minor surgical cases were highest in crossbred Jersey bulls $(2.35 \%)$ due to abscessation.

\section{References}

Arkins S 1981. Lameness in dairy cows. Irish Veterinary Journal. 35,135 - 40 \& 163 70.

DA Whitaker, JM Kelly and EJ Smith 1983. Incidence of lameness in dairy cows. Veterinary Record. 113, 60-62.

Dwight F Wolfe 2009. Penile and preputial conditions in bulls. $81^{\text {st }}$ Western Veterinary Conference. V 506.

G R Singh, Amarpal, H P Aithal and P Kinjavdekar 2005. Lameness in cattle a review. Indian journal of Animal Sciences 75 (6), 723-740.

J Hedges, R W Blowey, A.J. Packington, C.J. O'Callaghan and L E Green 2001. A longitudinal field trial of biotin on lameness in Dairy cows. Journal of Dairy Science. 84, 1969-75. 
Jubb T F and Malmo J 1991. Lesions causing lameness requiring veterinary treatment in pasture-fed dairy cows in EastGippsland. Australian Veterinary Journal 68, 21-4.

L D Warnick, D Janssen, C L Guard and Y T Grohn 2001. The effect of lameness on milk production in dairy cows. Journal of Dairy Science. 84, 1988-97.

P J Chenoweth 2003. Managing Herd Bulls on Large Dairies. $6^{\text {th }}$ Western Dairy
Management Conference, Department of Clinical Sciences, Kansas State University, Manhattan.

R P S Tyagi and Jit Singh 2004. Ruminant Surgery. Ist Edn., CBS Publications and Distributors, New Delhi.

Tranter W P and Morris R S 1991. A case study of lameness in three dairy herds. New Zealand Veterinary Journal. 150,151-64.

\section{How to cite this article:}

Sontakke, S.H., Vinod H. Shende, V.V. Potdar, H.D. Kadam, J.R. Khadse and Pande, A.B. 2019. Management of Surgical Affections in Breeding Bulls.

Int.J.Curr.Microbiol.App.Sci. 8(08): 826-829. doi: https://doi.org/10.20546/ijcmas.2019.808.094 